\title{
Paper Mill Sludge as a Source of Sugars for Use in the Production of Bioethanol and Isoprene
}

\author{
Shona M. Duncan ${ }^{1}$, Malek Alkasrawi ${ }^{1}$ **(D), Raghu Gurram ${ }^{1}$, Fares Almomani ${ }^{2}$, \\ Amy E Wiberley-Bradford ${ }^{3}$ and Eric Singsaas ${ }^{4}$ \\ 1 Wisconsin Institute for Sustainable Technology, University of Wisconsin-Stevens Point, Stevens Point, \\ WI 54481, USA; dshona@uwsp.edu (S.M.D.); rgurram@uwsp.edu (R.G.) \\ 2 Department of Chemical Engineering, Qatar University, P.O. Box 2713 Doha, Qatar; Falmomani@qu.edu.qa \\ 3 Department of Horticulture, University of Wisconsin-Madison, 1575 Linden Dr, Madison, WI 53706, USA; \\ wiberley@alumni.iastate.edu \\ 4 Natural Resources Research Institute, University of Minnesota Duluth, Duluth, MN 55812, USA; \\ esingsaa@d.umn.edu \\ * Correspondence: malkasra@uwsp.edu
}

Received: 5 August 2020; Accepted: 4 September 2020; Published: 8 September 2020

\begin{abstract}
Paper mill sludge (PMS) solids are predominantly comprised of cellulosic fibers and fillers rejected during the pulping or paper making process. Most sludges are dewatered and discharged into landfills or land spread at a cost to the mill; creating large economic and environmental burdens. This lignocellulosic residual stream can be used as a source of sugars for microbial fermentation to renewable chemicals. The aim of this study was to determine the possibility of converting mill sludge to sugars and then fermentation to either isoprene or ethanol. Chemical analysis indicated that the cellulosic fiber composition between 28 to $68 \%$ and hemicellulose content ranged from 8.4 to $10.7 \%$. Calcium carbonate concentration in the sludge ranged from 0.4 to $34 \%$. Sludge samples were enzyme hydrolyzed to convert cellulose fibers to glucose, percent conversion ranged from 10.5 to $98 \%$. Calcium carbonate present with the sludge resulted in low hydrolysis rates; washing of sludge with hydrochloric acid to neutralize the calcium carbonate, increased hydrolysis rates by 50 to $88 \%$. The production of isoprene "very low" (190 to $470 \mathrm{nmol}$ ) because the isoprene yields were little. Using an industrial yeast strain for fermentation of the sludge sugars obtained from all sludge samples, the maximum conversion efficiency was achieved with productivity ranging from 0.18 to $1.64 \mathrm{~g} \mathrm{~L}^{-1} \mathrm{~h}^{-1}$. Our data demonstrates that PMS can be converted into sugars that can be fermented to renewable chemicals for industry.
\end{abstract}

Keywords: sludge; hydrolysis; sugars; biofuels; calcium carbonate; lignocellulosic biomass

\section{Introduction}

Woody biomass is the largest source of renewable biomass and is traditionally used as feedstock for biofuel production [1,2]. During the wood digestion process millions of tons of both primary and secondary sludge are annually discarded in the USA; most is disposed of in landfills or incinerated at substantial cost to the industry. The cost to dispose of sludge will be different for each facility depending on the percent solids in the sludge and landfill fees [3-5]. The paper mill sludge (PMS) has a low heating value, 15.4-15.8 MJ/kg [6], due to the presence of inorganic fillers such as calcium carbonate. However, energy recovery efficiency depends on the nature of the sludge type and the deployed energy recovery technology.

In Wisconsin, a ballpark figure is US $\$ 30$ per dry ton to dispose of sludge in a landfill. For a large mill that produces 100 tons of sludge per day this cost could be as high as $\$ 1$ million per year for disposal, 
assuming 350 operating days per year and sludge of $50 \%$ solids (personal communication). Globally PMS generation is predicated to increasing the coming 50 years by 48 to $86 \%$ [7]. The consequences of PMS increase affect the landfill capacity and overload incinerator capacity [7]. More stringent environmental regulations are increasing the cost of landfilling or incinerating sludge which is limiting the disposal options of sludge [3]. Most of the environmental impact of landfilling sludge stems from gas and leachate generation during the decomposition process with liquid leachate runoff potentially contaminating land, groundwater, and surface water bodies [8]. Paper mill sludge incineration is an uneconomical option due to pollution risk of air, water and soil [9].

Likon and Trebše [9] present many options for potential processes which could turn this residual stream into value-added products rather than landfilling and incinerating. These options include: land surface application, composting, effective incineration, pyrolysis, indirect steam gasification, wet oxidation, supercritical water oxidation and gasification [10-12]. PMS contain large amount of inorganic fraction that can be used in the production of construction materials (bricks, light aggregates and cement production), material for landfill capping, sorbent material and heat insulation material. Due to PMS being physically and chemically complex waste, it could be utilized in various industrial applications including: as heat insulation, water absorbent, substitute for virgin fibers in the production of fiber-cement sheets, paper and wood adhesive, cat litter, retainer of agriculture pesticide or fertilizer and conversion of the cellulosic fiber into chemicals, additives or biofuels-for example, methyl tetrahydrofuran, an additive which can be mixed with fuel to make cleaner burning fuels.

An alternative use for this lignocellulosic biomass is to produce bioethanol, biobutanol and valuable products. Being a non-food-based biomass makes paper sludge an attractive underutilized cellulosic feedstock for conversion to renewable chemicals and biofuels. It does not need additional costly pretreatment as the sludge has already been pretreated during the pulping process, has negative feedstock cost, and can potentially be integrated into the current infrastructure at a pulp and paper mill [13].

To successfully convert the PMS to sugars, the sludge requires hydrolysis of the cellulose and hemicellulose to monosaccharides (predominately glucose and xylose). This can either be done enzymatically or chemically. Enzyme hydrolysis offers a more specific and milder option with reduced inhibitory compound formation. In ideal conditions cellulose hydrolysis rates can be as high as $100 \%$ [14].

The presence of fillers such as $\mathrm{CaCO}_{3}$, clay and titanium oxide with the cellulosic fibers is a major factor when considering uses of sludge as a feedstock. There are a variety of ways fillers can have a negative influence on the enzyme hydrolysis, including the possibility that fillers form an adhesive envelope around the cellulose fibers, obstructing access of the enzyme to the cellulose $[15,16]$. Chen et al. [17] reported results that showed that acid-soluble ash (calcium carbonate) and acid-insoluble ash (clay) adsorb enzymes with a greater affinity than cellulose fibers.

The development of sludge to biofuels processes, chemicals and proteins via a microbial/biochemical pathway has been studied for the past few decades by many researchers; bioethanol using Saccharomyces cerevisiae, Zymomonas mobilis $[15,18,19]$, methane using Thermotoga elfii and Caldicellulosiruptor saccharolyticus [20], hydrogen [21], lactic acid using Bacillus coagulans [13] and cellulase using Trichoderma reesei [22]. All have shown that pulp and paper sludge can be successfully enzyme hydrolyzed and fermented using a variety of microorganisms. Chen et al. [23] completed a financial analysis with assumption the fuel ethanol cost US $\$ 0.608$ per liter. Conversion of PMS (calcium carbonate and fillers removed) to ethanol economically feasible scenario.

The apparent physical properties of isoprene $\left(\mathrm{C}_{5} \mathrm{H}_{8}\right.$, 2-methyl-1, 3-butadiene) are colorless and highly volatile at room $25^{\circ} \mathrm{C}$ [24]. Isoprene found at very low concentrations in nature and is utilized as carbon source by several organisms eukaryotic and prokaryotic $[25,26]$. Isoprene is an important platform chemical essentially important for a production of chemicals such as synthetic rubber, sensitive adhesives, and elastomers. At present, isoprene is produced from petroleum derived feedstocks. 
The rubber industry depends on imported materials, either natural rubber from Hevea brasiliensis or petroleum for synthetic rubber polymers.

Following the above literature review, there is a gap knowledge on research work related to the use of paper sludge as a source of sugars and biofuel. Besides, there is discrepancies on the rule of calcium carbonate and other fillers present on the rate of conversion of cellulose fibers and sugar to biofuel (ethanol). Therefore, the present study illustrate for the first time the production of isoprene from a non-food feedstock pulp and paper sludge. The study evaluates the potential of pulp and paper sludge to produce bioethanol. The effect of calcium carbonate and other fillers present on biofuel production was investigated and the biofuel production was assessed accordingly. Moreover, the contribution of different sludge constituents (sugar, cellulose, fiber and lignocellulos) on the biofuel production was determined.

The objective of this work is to demonstrate the feasibility of converting pulp mill residuals into renewable chemicals. The concentration of calcium carbonate and other fillers present with the cellulose fibers needs to be reduced to ensure high saccharification rates. The present data that shows isoprene can be produced from pulp and paper sludge, a non-food feedstock of fermentable sugars. We provide more evidence of the potential to use pulp and paper sludge to produce bioethanol.

\section{Materials and Methods}

\subsection{Source of Sludge}

The sludges materials are mainly solid materials containing cellulosic fiber materials and inorganic filler. They obtained mainly from paper mill from the screw section where it separated the wastewater and the solid sludge. Sludge was collected from a mixed pulp source pulp and paper mill, two Kraft pulp and paper mills, a sulfite pulp and paper mill, and a sulfite specialty fibers mill (Table 1).

Five sludge samples were donated from three pulp and paper mills (A, B, C, D and E) in the U.S.A. The sludges A and C obtained from central Wisconsin State. The sludge B obtained from Lake Superior/Minnesota State and a D and E obtained from fibers mill in Washington State. Sludge samples were collected from each paper mill and stored in sealed buckets in a cold room at $4{ }^{\circ} \mathrm{C}$. Smaller samples of the sludge used for chemical analysis, sugar production and fermentation studies were taken from the sealed buckets as needed.

Table 1. Mill labels and types of pulp produced. Characterization of solids content, inorganic and calcium carbonate content of mill sludge samples. A, B, C, D, E unwashed, A2, B2, D2, HCl washed and D3 water washed. Inorganic and calcium carbonate content expressed as a percentage of total biomass dry weight $( \pm$ S.D. $)(n=3)$.

\begin{tabular}{|c|c|c|c|c|}
\hline \multicolumn{2}{|r|}{-} & \multicolumn{3}{|c|}{ Content, \% of Dry Weight Basis } \\
\hline Mill & Paper Mill Sludge Identity & Solids & Ash & $\mathrm{CaCO}_{3}$ \\
\hline A & $\begin{array}{l}\text { Combination Kraft pulp, ground } \\
\text { wood pulp and recycled paper mill }\end{array}$ & $56.46 \pm 2.41$ & $53.42 \pm 0.78$ & $34.18 \pm 0.47$ \\
\hline $\mathrm{A} 2$ & $\begin{array}{lll}y^{2} & 1 & -\end{array}$ & $31.90 \pm 0.56$ & $12.97 \pm 0.88$ & $12.65 \pm 2.19$ \\
\hline $\mathrm{B}$ & Kraft pulp and paper mill & $26.25 \pm 0.90$ & $28.52 \pm 0.79$ & $23.42 \pm 0.56$ \\
\hline B2 & - & $24.70 \pm 0.63$ & $11.04 \pm 1.78$ & $11.83 \pm 0.15$ \\
\hline $\mathrm{C}$ & Kraft pulp and paper mill & $36.80 \pm 1.40$ & $23.20 \pm 1.62$ & $18.03 \pm 1.03$ \\
\hline $\mathrm{D}$ & Sulfite pulp and paper mill & $18.67 \pm 0.44$ & $27.24 \pm 1.74$ & $19.26 \pm 2.30$ \\
\hline D2 & 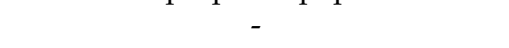 & $9.50 \pm 0.14$ & $7.45 \pm 1.23$ & $4.98 \pm 0.29$ \\
\hline D3 & - & $13.34 \pm 0.04$ & $28.44 \pm 1.15$ & $20.64 \pm 1.03$ \\
\hline $\mathrm{E}$ & Sulfite pulp, specialty fibers & $24.76 \pm 2.51$ & $1.14 \pm 0.21$ & $0.38 \pm 0.13$ \\
\hline
\end{tabular}

\subsection{Chemical Compostional Analysis}

All sludge samples were analyzed in triplicate for solids (NREL Laboratory Analytical Procedure NREL/TP-510-42622), inorganic material by ashing at $575{ }^{\circ} \mathrm{C}$ (NREL Laboratory Analytical Procedure 
NREL/TP-510-42621) and calcium carbonate by ashing at $900^{\circ} \mathrm{C}$. Klason lignin (acid insoluble lignin) and carbohydrate content of the sludge were analyzed in triplicate using NREL Laboratory Analytical Procedure (NREL/TP-510-42618) [27]. Sugars in the unwashed sludge were measured by mixing paper sludge ( $100 \mathrm{~g}$ ) with $500 \mathrm{~mL}$ of distilled water, stirring at $550 \mathrm{rpm}$ for $45 \mathrm{~min}$. The suspension was filtered through a glass fiber filter paper. The sugars in the filtrate were analyzed by ion chromatography (Section 2.3).

\subsection{Ion Chromatography}

Glucose, xylose, arabinose, galactose and mannose were determined against a fucose internal standard in the Ion-Chromatography System (Dionex ICS 3000 Thermo Scientific Waltham, MA, USA). The electrochemical detection used gold electrode, placed after the two guard columns (an Amino Trap Bio1C and a Carbo Pac PA1 (Dionex)) and a $4 \times 250 \mathrm{~mm}$ Carbopac PA1 column (Dionex) maintained at $25{ }^{\circ} \mathrm{C}$ was used. The eluents were $3 \mathrm{mM} \mathrm{NaOH}, 300 \mathrm{mM} \mathrm{NaOH}$ and deionized-water. The eluents degassed using a vacuum and flow through the column at a flow rate of $1 \mathrm{~mL} / \mathrm{min}$. The sugars were eluted using the following gradient -3 to $0 \mathrm{~min} 100 \% 3 \mathrm{mM} \mathrm{NaOH}, 0-3 \mathrm{~min} 100 \% 3 \mathrm{mM} \mathrm{NaOH}, 3-45 \mathrm{~m}$ $100 \% 3 \mathrm{mM} \mathrm{NaOH}$ to $80 \% 3 \mathrm{mM} \mathrm{NaOH}$ and $20 \%$ ultrapure water and $45-50 \mathrm{~min} 100 \% 300 \mathrm{mM} \mathrm{NaOH}$.

The ethanol determined in a Dionex ICS 3000 with an electrochemical detector with platinum electrode, an Ion-Pac ICE-AS1 guard columns (Dionex) and a $4 \times 250 \mathrm{~mm}$ Ion-Pac ICE-AS1 column (Dionex) maintained at $25^{\circ} \mathrm{C}$ was used. The eluent was $100 \mathrm{mM}$ methanesulfonic acid prepared with degassed deionized water using vacuum and was run through the column at a flow rate of $0.18 \mathrm{~mL} \mathrm{~min}^{-1}$.

\subsection{Hydrolytic Enzymes}

Commercial enzyme Cellic ${ }^{\circledR}$ (Bagsværd, Denmark) Ctec 2 (liquid) from the fungus Trichoderma reseei, consisting of a blend of aggressive cellulases, $\beta$-glucosidase and hemicellulase was provided by Novozymes. Cellulase activity (filter paper assay) was determined according to the National Renewable Energy Laboratory Standard Procedure (NREL/TP-510-42628). The cellulase (Filter Paper units (FPU)) activity was estimated to be $113.8 \mathrm{FPU} \mathrm{ml} / \mathrm{mL}$.

\subsection{Removal of Fillers from Sludge}

When necessary the sludge was washed with either hydrochloric acid $(\mathrm{HCl})$ or distilled water. Hydrochloric acid washing was performed according to methods described by Gurram et al. [15] and left stirring overnight. The suspension was filtered through a glass fiber filter paper and washed twice with distilled water, filtered to dry and the washed sludge was stored at $4{ }^{\circ} \mathrm{C}$. For the water only based washing, $500 \mathrm{~g}$ sludge was mixed with $5 \mathrm{~L}$ of distilled water for $2 \mathrm{~h}$. The suspension was filtered through a nylon mesh stocking, the retained sludge was further washed under a stream of running water, excess water was squeezed out and the washed sludge was stored at $4{ }^{\circ} \mathrm{C}$. Concentration of sugars released during the washing process was determined by ion chromatography (Section 2.3). The wastewater after fiber recovery was discarded and not used in the fermentation since it contains inhibitors to the microbes.

\subsection{Enzyme Hydrolysis}

The enzyme hydrolysis trails conducted in triplicate following the NREL protocol guidelines (NREL/TP-510-42629) [28]. One-gram dry weight of either untreated, $\mathrm{HCl}$ washed or water washed sludge was suspended in citrate buffer $(0.05 \mathrm{M}, \mathrm{pH} 4.8)$ in a $125 \mathrm{~mL}$ bottle (Wheaton) total working volume $30 \mathrm{mls}$. Sodium azide was added at $0.2 \%(w / v)$ as the anti-microbial agent. The enzyme solution was added at various enzyme concentrations of 2.3, 5.7 and 9.1 FPU per g biomass (dry weight). The enzymatic hydrolysis operated at $50{ }^{\circ} \mathrm{C}$ at $120 \mathrm{rpm}$ for $72 \mathrm{~h}$ in a shaker incubator. Samples of $0.5 \mathrm{~mL}$ were withdrawn at $0,8,24,32,48,56$ and $72 \mathrm{~h}$, was centrifuged at $13,000 \mathrm{rpm}$ for $4 \mathrm{~min}$. The production of glucose and xylose in the supernatant was evaluated by ion chromatography (IC) 
(Section 2.3) after samples were filtered through a $0.2 \mu \mathrm{m}$ filter membrane and diluted. Hydrolysis yield was determined by the ratio between the sugars produced and the initial carbohydrate content in the sludge samples used.

Sugar solutions for fermentation were produced using the above method except that the solids content was increased to $15 \%$ (dry weight), the volume was increased to $1 \mathrm{~L}$ and the hydrolysis was completed in a $3 \mathrm{~L}$ bioreactor (New Brunswick, NJ, USA) at $50{ }^{\circ} \mathrm{C}$ at $120 \mathrm{rpm}$ until sugar level in the solution reached a constant value.

\subsection{Isoprene Headspace Vial}

Our objective was to determine the potential to produce isoprene via fermentation of the liquid sugar extracts obtained from the enzymatic hydrolysis of washed sludge from Mill $\mathrm{A}$ and B and unwashed sludge from Mill C, D and E. Cultures of the strain Escherichia coli BL21 H8 (2C-methyl-D-erythritol 4-phosphate (MEP) pathway, Isoprene Eight-Gene Operon Cloned on pJAZZ + Isoprene Synthase on a plasmid) (gift from C5.6, Middleton, WI, USA) were grown in Luria-Bertani (Miller) broth (LB) (Difco) (containing $25 \mu \mathrm{g} / \mathrm{mL}$ kanamycin, $25 \mu \mathrm{g} / \mathrm{mL}$ chloramphenicol and $0.15 \%$ glucose) at $37^{\circ} \mathrm{C}$ with shaking overnight. Aliquots of cultures were transferred to $20-\mathrm{mL}$ headspace vials (containing $10 \mathrm{~mL}$ LB with $25 \mu \mathrm{g} / \mathrm{mL}$ kanamycin, $25 \mu \mathrm{g} / \mathrm{mL}$ chloramphenicol, inducer $(0.2 \%$ rhamnose $)$ and sludge sugar solution at $0.15 \%$ glucose $)$ in triplicate. Isoprene production using a blank consisting of cultures of Escherichia coli BL21 H8 grown in a 20-mL headspace vials containing $10 \mathrm{~mL}$ LB with $25 \mu \mathrm{g} / \mathrm{mL}$ kanamycin, $25 \mu \mathrm{g} / \mathrm{mL}$ chloramphenicol, no inducer and $0.15 \%$ glucose was tested. The cultures were incubated at $37^{\circ} \mathrm{C}$ with agitation using the Standard-Agitator for the GERSTEL MultiPurpose Sampler (MPS) for $24 \mathrm{~h}$. The isoprene was determined in a gas chromatography-mass spectrometry (GC-MS) system, an Agilent 7890A GC and 5975 mass selective detector (MSD) (Agilent, Santa Clara, CA, USA) equipped with autosampler (Gerstel multipurpose sampler MPS2XL, Mülheim an der Ruhr, Germany). The autosampler with a $2.5 \mathrm{~mL}$ headspace syringe removed a $1 \mathrm{ml}$ sample of headspace gas and injected it into the GC. A HP-5MS 5\%Phenyl Methyl Siloxane column (30 mm length; $0.25 \mathrm{~mm}$ inner diameter, $0.25 \mu \mathrm{m}$ film thickness,) with helium as the carrier gas at a flow rate of $0.927 \mathrm{~mL} \mathrm{~min}^{-1}$ was used. The inlet temperature was $150^{\circ} \mathrm{C}$ and the oven temperature was equilibrated at $65^{\circ} \mathrm{C}$ for $0.5 \mathrm{~min}$ and was then held at $65^{\circ} \mathrm{C}$ for the length of the run $(2.5 \mathrm{~min})$. In order to determine the isoprene production from the fermentation trails, a reference peak retention times and mass spectra (NIST Chemistry WebBook, NIST Standard Reference Database Number 69) were used to compared with the standard isoprene solution. The time when isoprene eluted estimated to be at $1.8 \mathrm{~min}$.

The isoprene concentrations from the bacterial fermentation were determined by converting the GC-MS peak area to nmol of isoprene via a calibration curve. Bacterial growth was monitored by optical density of the cell suspension at $600 \mathrm{~nm}$ using a UV-Visible Spectrophotometer (Evolution $60 \mathrm{~S}$ Thermo Scientific, Waltham, MA, USA) at time 0 and at $24 \mathrm{~h}$. Glucose consumption was analyzed using IC as described previously (Section 2.3).

\subsection{Ethanol Fermentation}

To determine the potential to produce ethanol by fermentation of the liquid sugar extracts obtained from the enzymatic hydrolysis of washed sludge from Mill A and B and unwashed sludge from Mill C, $\mathrm{D}$ and $\mathrm{E}$, a method similar to that used by Gurram et al. [15] was used. The inoculum was prepared in a $250 \mathrm{~mL}$ flask with $100 \mathrm{mls}$ of the media described above but with $50 \mathrm{~g} \mathrm{~L}^{-1}$ glucose and the FermPro yeast strain was transferred from an agar plate. The broth was incubated at $30^{\circ} \mathrm{C}, 150 \mathrm{rpm}$ overnight in an orbital shaker incubator before inoculation into test media. The enzyme hydrolysates were supplemented with $10 \mathrm{~g} \mathrm{~L}^{-1}$ yeast extract and $20 \mathrm{~g} \mathrm{~L}^{-1}$ peptone. Fermentation experiments took place in triplicate using $125 \mathrm{~mL}$ Erlenmeyer flasks containing a total working volume of $55 \mathrm{~mL}$. A $10 \% v / v$ inoculum of FermPro yeast strain (Ferm Solutions, Danville, KY, USA) was added to the fresh medium. Samples were collected along the $48 \mathrm{~h}$ incubation period. Yeast growth was monitored by optical 
density of the cell suspension at $540 \mathrm{~nm}$ using a spectrophotometer. Glucose consumption and ethanol production were determined using IC as previously described in Section 2.3. Maximal ethanol yield (\%, g ethanol/g glucose) was calculated as the grams of ethanol produced from a gram of glucose. Productivity was determined by the ratio between ethanol concentration produced and the corresponding time needed to reach such concentration.

\section{Results and Discussion}

\subsection{Analysis of Mill Sludge}

Solids content (Table 1) of the unwashed sludge varied from 56\% (Mill A) to 19\% (Mill D). For the unwashed sludge, the inorganic content determined by furnace drying at $575{ }^{\circ} \mathrm{C}$ ranged from $53 \%$ (Mill A) to 1.0\% (Mill E) (Table 1). Table 2 present the chemical compositional analysis of all paper mill sludges. Ignition of unwashed sludge samples at $900{ }^{\circ} \mathrm{C}$ converted calcium carbonate to calcium oxide; for the unwashed sludge samples the calcium carbonate content (Table 1) ranged from $34 \%$ (Mill A) to $0.4 \%$ (Mill E). It was expected that Mill A sludge would contain high calcium carbonate and filler levels as the mill uses recycle paper (high in calcium carbonate and other fillers) as its pulp source, while Mill E does not make paper so does not use calcium carbonate or other fillers. Sludge samples that contain no inorganic fillers or coating other than calcium carbonate will give essentially identical results from ashing at $575{ }^{\circ} \mathrm{C}$ and $900{ }^{\circ} \mathrm{C}$. As seen from Table 1 before HCL washing, Mill A had a difference between ash and calcium carbonate of $53.5 \%$ and $34.2 \%$ respectively. In contrast, after HCL washing the same mill had numbers that were identical, 12.97 and 12.65 respectively this indicates that calcium carbonate was not the only filler in this sludge.

Gurram et al. [15] investigated a variety of methods and chemicals for the removal of calcium carbonate from primary sludge. The most effective was acid neutralization with HCL which was the method used to remove calcium carbonate from the sludge used in this research. Sludge samples with high calcium carbonate levels were washed with 1M HCL using the balanced equation

$$
\mathrm{CaCO}_{3}+2 \mathrm{HCl} \rightarrow \mathrm{CaCl}_{2}+\mathrm{CO}_{2}+\mathrm{H}_{2} \mathrm{O}
$$

This successfully converted the insoluble calcium carbonate to soluble calcium chloride which could be rinsed from the sludge sample with filtration and washing, but not as efficiently as reported by Gurram et al. [15] who reported $\mathrm{CaCO}_{3}$ concentration reduction from $27 \%$ to $0.5 \% w / w$ (dry weight basis) using $\mathrm{HCl}$. This procedure was used to reduce the calcium carbonate content from three (A, B, D) of the 5 sludge samples (creating samples A2, B2 and D2). The technique was not used on sludge from Mill C or Mill E due to successful enzyme hydrolysis of Mill C sludge (Table 3) and low calcium carbonate levels along with successful enzyme hydrolysis of sludge from Mill E (Tables 1 and 3). The washing of the sludge reduced calcium carbonate levels by between 50 to $75 \%$. Sludge D was also washed with water as washing with HCL appeared to cause a loss of carbohydrates (Table 2), indicating that the filler used at this mill is not predominately calcium carbonate; however washing with water (created sample D3) did not appear to remove calcium carbonate or other fillers as the values are similar to unwashed sludge values (Table 1). After washing with HCL, the percent ash at $575^{\circ} \mathrm{C}$ and $900^{\circ} \mathrm{C}$ for 2 of the 3 (Mill A, B and D) sludge samples that were washed were essentially identical; but for sludge from Mill D, although the \% ash in the samples had dropped, the values were still quite different $575{ }^{\circ} \mathrm{C}, 7.45 \%$ and $900{ }^{\circ} \mathrm{C}, 5 \%$.

The carbohydrate and lignin content of the mill sludge samples were analyzed and the results presented in Table 2. Cellulose is a polymer of $\beta$-D-glucopyranose moieties linked via $\beta$-(1,4) glycosidic bonds. Therefore, cellulose is analytically measured in terms of glucan content. Due to calcium carbonate neutralizing the $72 \%$ sulfuric acid during the acid hydrolysis method, the carbohydrate and lignin content of the unwashed Mill A and Mill B was calculated from the washed sludge results, taking into account less lignocellulosic biomass due to increased inorganics content. The highest total sugars content was present in Mill E sludge (78\%) and the lowest was present in Mill D sludge after 
$\mathrm{HCl}$ washing (17\%). The highest cellulose content was present in Mill E sludge (68\%) and the lowest was present in Mill D sludge after $\mathrm{HCl}$ washing (4\%). The highest hemicellulose content was present in Mill A after washing (18\%) and the lowest was present in Mill D after washing ( $4 \%$ ). The highest lignin content was present in Mill E sludge (26\%) and the lowest was present in Mill A sludge before washing $(7.5 \%)$. It is expected that the carbohydrate and lignin levels in the sludge samples would increase after removal of calcium carbonate and fillers. No free sugars were detected in any of the sludge samples.

Table 2. Characterization of chemical constituents (dry weight basis) in the various sludge samples. All expressed as a percentage of total biomass dry weight. The same sludge materials used in study conducted by Gurram et al. [15].

\begin{tabular}{cccccccc}
\hline Mill & $\begin{array}{c}\text { Lignin } \\
\mathbf{( \% )}\end{array}$ & $\begin{array}{c}\text { Glucan } \\
\mathbf{( \% )}\end{array}$ & $\begin{array}{c}\text { Xylan } \\
\mathbf{( \% )}\end{array}$ & $\begin{array}{c}\text { Mannan } \\
\mathbf{( \% )}\end{array}$ & $\begin{array}{c}\text { Arabanan } \\
\mathbf{( \% )}\end{array}$ & $\begin{array}{c}\text { Galactan } \\
\mathbf{( \% )}\end{array}$ & $\begin{array}{c}\text { Total Sugars } \\
\mathbf{( \% )}\end{array}$ \\
\hline A & 7.56 & 40.98 & 10.31 & 2.03 & 0.33 & 0.88 & 54.53 \\
A2 & 10.28 & 55.73 & 14.02 & 2.75 & 0.45 & 1.20 & 74.15 \\
B & 21.34 & 40.86 & 7.66 & 1.98 & 0.09 & 1.79 & 52.38 \\
B2 & 25.24 & 48.18 & 9.03 & 2.33 & 0.11 & 2.11 & 61.77 \\
C & 19.22 & 34.30 & 5.02 & 1.92 & 0.16 & 1.29 & 42.69 \\
D & 19.58 & 31.96 & 6.32 & 1.29 & 0.30 & 1.57 & 41.44 \\
D2 & 28.69 & 13.82 & 0.61 & 0.00 & 0.00 & 3.45 & 17.89 \\
D3 & 21.86 & 13.17 & 0.00 & 0.00 & 0.00 & 9.88 & 23.05 \\
E & 26.0 & 68.05 & 1.23 & 0.00 & 0.00 & 9.24 & 78.53 \\
\hline
\end{tabular}

Table 3. Enzyme hydrolysis yield (Cellulose-to-glucose and Xylan to Xylose (wt\%) ( \pm S.D. $))(n=3)$.

\begin{tabular}{ccccc}
\hline Mill & $\begin{array}{c}\text { Glucose Release at } \\
\mathbf{2 4} \mathbf{~ h}\end{array}$ & $\begin{array}{c}\text { Maximum } \\
\text { Glucose Release }\end{array}$ & $\begin{array}{c}\text { Xylose Release at } \\
\mathbf{2 4} \mathbf{~ h}\end{array}$ & $\begin{array}{c}\text { Maximum } \\
\text { Xylose Release }\end{array}$ \\
\hline A & $10.51 \pm 1.89$ & $14.23 \pm 6.97$ & $11.80 \pm 1.03$ & $17.28 \pm 1.20$ \\
A2 & $60.30 \pm 1.41$ & $71.81 \pm 0.72$ & $50.66 \pm 2.82$ & $50.66 \pm 2.82$ \\
B & $13.42 \pm 2.28$ & $13.34 \pm 2.82$ & $13.34 \pm 0.51$ & $11.66 \pm 0.34$ \\
B2 & $67.28 \pm 1.0$ & $67.28 \pm 1.0$ & $62.32 \pm 0.88$ & $62.32 \pm 0.88$ \\
C & $97.70 \pm 10.46$ & $98.90 \pm 0.32$ & $97.78 \pm 11.03$ & $97.78 \pm 11.03$ \\
D & $26.29 \pm 3.55$ & $26.29 \pm 3.55$ & $5.48 \pm 0.81$ & $5.48 \pm 0.81$ \\
D2 & $87.66 \pm 2.86$ & $95.37 \pm 5.28$ & $90.66 \pm 4.01$ & $97.37 \pm 2.52$ \\
D3 & $46.35 \pm 3.95$ & $51.53 \pm 5.28$ & 0.00 & 0.00 \\
E & $69.38 \pm 1.12$ & $76.59 \pm 4.39$ & $68.42 \pm 16.37$ & $73.30 \pm 2.79$ \\
\hline
\end{tabular}

\subsection{Enzyme Hydrolysis of Sludge Samples}

Mill A sludge unwashed (which had the highest content of inorganic material) was the only sludge sample in which enzyme concentration appeared to affect the maximum glucose release. The lower the enzyme concentration, the lower the maximum glucose release 2.3 ( $3.1 \%$ glucose release), 5.7 (13.2\% glucose release) and 9.1(14.2\% glucose release) FPU per g biomass (dry weight). For all the other sludge samples either unwashed, $\mathrm{HCl}$ washed and water washed the various enzyme concentrations 2.3, 5.7 and 9.1 FPU per g biomass (dry weight) affected the rate of glucose release (the higher the enzyme concentration the quicker maximum glucose release was achieved) but overall, the same maximum levels of glucose release was achieved by all 3 enzyme dose rates by the end of the experiment (72 h) (data not shown). The time of maximum percent enzyme hydrolysis varied between the sludge samples ranging from 8 to $72 \mathrm{~h}$ (Table 3) so to compare sludge samples $24 \mathrm{~h}$ and $9.1 \mathrm{FPU}$ per $g$ biomass (dry weight) were chosen as the time point and enzyme concentration. The highest $\%$ glucose release after $24 \mathrm{~h}$ from the various mill sludge samples was Mill C $(99 \%)$ and the lowest was $10.5 \%$ (Mill A unwashed) (Table 3). The presence of fillers in the sludge samples reduced the enzyme hydrolysis rate and the speed of hydrolysis for example Mill A sludge which contained $34 \% \mathrm{CaCO}_{3}$ the maximum hydrolysis of cellulose was $14 \%$ after $56 \mathrm{~h}$ but when the $\mathrm{CaCO}_{3}$ content was reduced 
to $12.6 \%$ by washing with HCL, the maximum hydrolysis of cellulose increased to $72 \%$ after $48 \mathrm{~h}$. Due to the presence of hemicellulases in Cellic ${ }^{\circledR}$ Ctec 2 xylose was also released from xylan present in the sludge during the hydrolysis process. The highest $\%$ xylose release after $24 \mathrm{~h}$ from the various mill sludge samples was Mill C at $98 \%$ and the lowest was 5.5\% (Mill D unwashed). Mill D after washing with either $\mathrm{HCl}$ or water, the levels of xylan were too small to accurately determine enzymatic hydrolysis release of xylose.

\subsection{Isoprene Fermentation}

Several plants produce naturally isoprene, with high volatility exhibiting challenges of recovery and condensation $[29,30]$. Isoprene was produced using Escherichia coli BL21 H8 from all sludge sugar solutions. For 4 of the 5 sludge sugar solutions, the amount of isoprene produced was higher than the blank (which contained no glucose) and equal or higher than pure glucose (Figure 1). Minimal to no isoprene was observed using sugar solution from Mill D sludge. The conversion rate was very low for all sludge samples, and to be commercially viable isoprene levels would have to rise significantly from the levels reported in this paper. In theory, one isoprene molecule can be produced from 1.25 glucose molecules via the MEP pathway. Escherichia coli BL21 H8 grew in the presence of all five sludge sugars, indicating that there were very little or no inhibitory factors in the sugar solutions. For the five sludge samples, the isoprene production ranged from 190 to $470 \mathrm{nmol}$. The variation of the isoprene titer is related to the nature of inhibitory presence in the sludge. The nature of inhibitory substances is related to the type of pulping technology that generate the sludge waste. However, the titer for isoprene production via fermentation is rather low due to the nature of microbial metabolic pathway. The low yield of $E$. coli is related to an imbalanced distribution of pyruvate and glucose-3-phosphate [29,31]. Gao et al. [32] reported cyanobacteria produced $1.26 \mathrm{~g} / \mathrm{L}$ isoprene from $\mathrm{CO}_{2}$. Yang et al. [33] reported a genetic Escherichia coli YJM13 with ispSPa gene produced isoprene up to $0.00248 \mathrm{~g} / \mathrm{L}$ and $0.532 \mathrm{~g} / \mathrm{L}$ when growing in under batch and fed-batch fermentation operation mood, respectively. The current results of isoprene production are in agreement with other studies [24,32-34] but for first time we report the isoprene production from sugar derived from PMS. In order, to tackle the preset challenges of low yield metabolic engineering provide high a feasible approach. For example, the optimized expression of the ispS gene enhanced isoprene production to 0.199 and $0.337 \mathrm{~g} / \mathrm{L}$, respectively [35]. Isoprene produced microbially via two metabolic pathways, the mevalonate pathway (MVA) and 2-C-methyl-D-erythritol 4-phosphate pathway (MEP). These two pathways are very crucial in tuning the isoprene titer. Understanding of their reaction kinetics opens new opportunities for maximizing the yield and lowering the fermentation time [29].

\subsection{Ethanol Production}

Ethanol was produced by the FermPro yeast strain from all sludge sugar solutions. The FermPro yeast strain grew in the presence of all five sludge sugars (glucose concentrations ranged from 3 to $28 \mathrm{~g} \mathrm{~L}^{-1}$ (Table 4)). Given that one mole of glucose is converted into two moles of ethanol and two moles of carbon dioxide the maximum conversion efficiency of glucose to ethanol is $51 \%$; for four of the five sludge sugar solutions, the amount of ethanol produced was the maximum conversion efficiency and equal to pure glucose (Table 4). The ethanol production from sludge sugar solution from Mill A was approximately half of the maximum conversion efficiency at $26.83 \%$, yeast growth rate was also slower when grown in media supplemented with Mill A sugar solutions. Apart from the sugar solution from Mill A, all the glucose was consumed during the fermentation, Mill D the fastest due to glucose concentration being approximately eight times less than the other sludge sugar solutions. Glucose alone had the highest productivity rate of $1.65 \mathrm{~g} \mathrm{~L}^{-1} \mathrm{~h}^{-1}$ and for the sugar solutions the highest productivity rate was Mill C, and productivity ranged from 0.18 to $0.71 \mathrm{~g} \mathrm{~L}^{-1} \mathrm{~h}^{-1}$. 


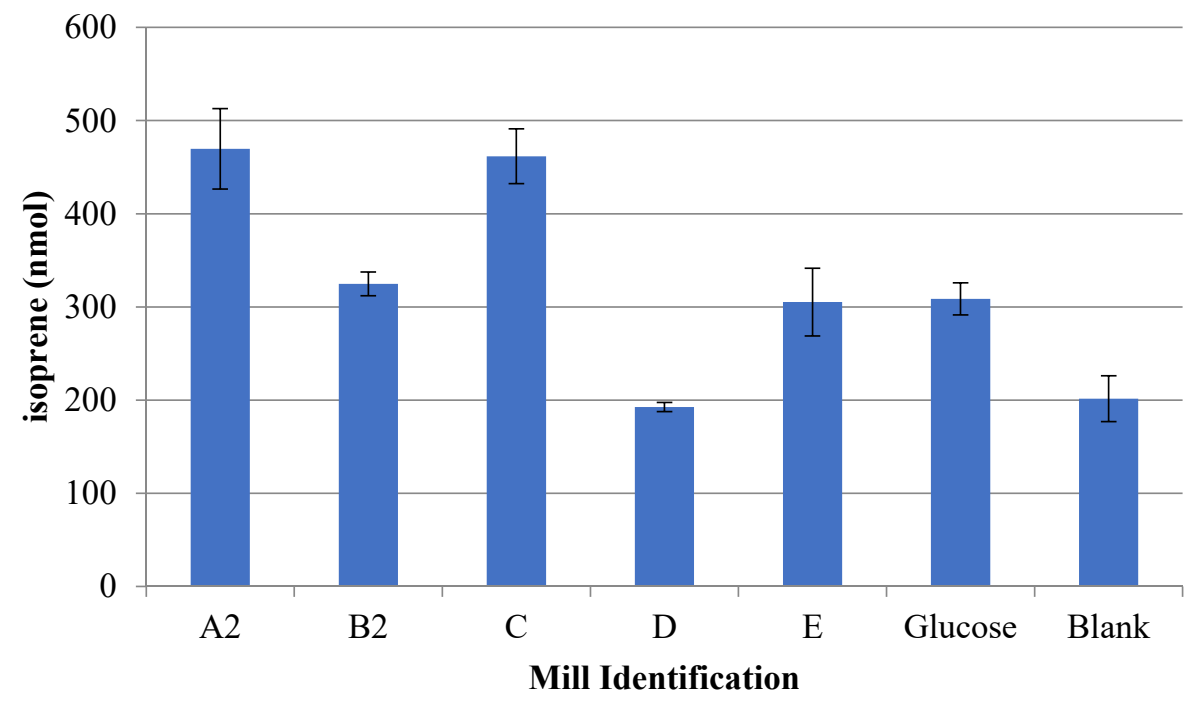

Figure 1. Maximal isoprene yield nmol isoprene in headspace gas. $( \pm$ S.D. $)(n=3)$.

Table 4. Total glucose concentration of sugar solution from Mills A2, B2, C, D and E, Number hours for consumption of all glucose, Maximal ethanol yield (\%, g ethanol/g glucose) and the productivity of the ethanol production (g ethanol $\left.\mathrm{L}^{-1} \mathrm{~h}^{-1}\right)( \pm$ S.D.) $(n=3)$.

\begin{tabular}{ccccc}
\hline Mill & $\begin{array}{c}\text { Total Glucose } \\
\left(\mathbf{g ~ L}^{-\mathbf{1}}\right)\end{array}$ & $\begin{array}{c}\text { Consumption of } \\
\text { Glucose }(\mathbf{h r})\end{array}$ & $\begin{array}{c}\text { Max. Ethanol } \\
\text { Yield (\%) }\end{array}$ & $\begin{array}{c}\text { Productivity } \\
\left(\mathbf{g ~ L ~ L ~}^{-\mathbf{1}} \mathbf{~ h}^{-\mathbf{1})}\right.\end{array}$ \\
\hline A2 & $27.87 \pm 5.54$ & $>48$ & $26.83 \pm 4.02$ & $0.28 \pm 0.08$ \\
B2 & $19.75 \pm 0.62$ & 32 & $50.90 \pm 1.77$ & $0.41 \pm 0.01$ \\
C & $25.34 \pm 1.04$ & 24 & $49.84 \pm 0.43$ & $0.71 \pm 0.65$ \\
D & $3.19 \pm 0.43$ & $<8$ & $53.15 \pm 0.93$ & $0.18 \pm 0.008$ \\
E & $25.77 \pm 0.19$ & 24 & $52.71 \pm 0.60$ & $0.57 \pm 0.01$ \\
Glucose & $25.67 \pm 0.14$ & 8 & $51.79 \pm 1.27$ & $1.65 \pm 0.04$ \\
\hline
\end{tabular}

Future work is required to overcome the influence of calcium carbonate and fillers on the enzyme hydrolysis. There are many methods for the removal of calcium carbonate including addition of acid, alkali, water washing, biological adsorbent $[36,37]$ and the use of flotation and electrocoagulation. The recycling of the calcium carbonate at low cost back to the mill for reuse or the production of other value-added chemicals from the process would be the ultimate goal. During the neutralization of the calcium carbonate with HCL, calcium chloride and carbon dioxide are produced. Both have potential markets; calcium carbonate for deicing and dust control on roads, road construction and as an additive for faster concrete curing and carbon dioxide can be collected and processed to produce liquid $\mathrm{CO}_{2}$ and dry ice.

\section{Conclusions}

In this manuscript, we demonstrated that sludge from pulp and paper mills in the USA (a non-food feedstock) are a good source of sugars that can be successfully enzyme hydrolyzed and fermented to isoprene or ethanol. Carbohydrate content of all five mill sludge samples was high enough to be considered for enzyme hydrolysis and fermentation. Successfully enzyme hydrolyzed of all sludge samples was achieved; three of the sludges required washing with HCL to neutralize the calcium carbonate before successfully enzyme hydrolyzed. Maximum conversion efficiency of glucose to ethanol was achieved for four of the five sludge sugar solutions using an industrial yeast strain and isoprene was produced by a developmental organism from four of the five sludge sugar solutions. The recycling of the calcium carbonate back to the mill for reuse or the production of other value-added 
chemicals from the process would be the ultimate goal as this will greatly improve the overall economics of the pulp and paper industry.

Author Contributions: Conceptualization, S.M.D., E.S., M.A., R.G.; methodology, S.D., E.S., M.A., R.G., F.A.; validation, S.D., E.S., M.A., R.G., F.A.; formal analysis, S.D.; investigation, S.D.; resources, A.E.W.-B.; writing — original draft preparation, S.D.; writing—review and editing, S.D., E.S., M.A., R.G.; visualization, S.D., E.S., M.A., R.G., F.A.; supervision E.S., M.A. All authors have read and agreed to the published version of the manuscript.

Funding: This research received no external funding.

Acknowledgments: Thank you to all the staff at the four mills for providing us with sludge samples and information on mill process for this study. The authors are grateful to Donald Guay, Senior Research Scientist, NewPage Corporation Research \& Development for his expertise and guidance. This research is sponsored as a part of an Economic Development Incentive Grant from the University of Wisconsin System.

Conflicts of Interest: The authors declare no conflict of interest.

\section{References}

1. Almomani, F.; Bhosale, R.R. Enhancing the production of biogas through anaerobic co-digestion of agricultural waste and chemical pre-treatments. Chemosphere 2020, 255, 126805. [CrossRef]

2. Almomani, F.; Shawaqfah, M.; Bhosale, R.R.; Kumar, A.; Khraisheh, M.A.M. Intermediate ozonation to enhance biogas production in batch and continuous systems using animal dung and agricultural waste. Int. Biodeterior. Biodegrad. 2017, 119, 176-187. [CrossRef]

3. Saha, N.; Saba, A.; Saha, P.; McGaughy, K.; Franqui-Villanueva, D.; Orts, W.J.; Hart-Cooper, W.M.; Reza, M.T. Hydrothermal carbonization of various paper mill sludges: An observation of solid fuel properties. Energies 2019, 12, 858. [CrossRef]

4. Al Momani, F.A.; Schaefer, S.; Sievers, M. Effect of ozone pre-treatment on sludge production of aerobic digestion processes. Int. J. Sustain. Eng. 2011, 4, 181-189. [CrossRef]

5. Balkaya, M. Assessment of the geotechnical aspect of the use of paper mill sludge as landfill cover and bottom liner material. Desalin. Water Treat. 2019, 172, 70-77. [CrossRef]

6. Zhang, L.; Xu, C.C.; Champagne, P. Energy recovery from secondary pulp/paper-mill sludge and sewage sludge with supercritical water treatment. Bioresour. Technol. 2010, 101, 2713-2721. [CrossRef]

7. Vaskova, I.; Jeng, R.; Tyagi, V.; Rodriguez, A.; Sain, M. Extracellular proteins produced by different species of the fungus trichoderma on secondary paper mill sludge substrate. BioResources 2012, 7, 1029-1039.

8. Bajpai, P. Management of Pulp and Paper Mill Waste; Springer: Berlin/Heidelberg, Germany, 2015.

9. Likon, M.; Trebše, P. Recent advances in paper mill sludge management. In Industrial Waste; InTech: Rijeka, Croatia, 2012; pp. 73-90.

10. Bhosale, R.R.; Sutar, P.; Kumar, A.; AlMomani, F.; Ali, M.H.; Ghosh, U.; AlMuhtaseb, S.; Khraisheh, M. Solar hydrogen production via erbium oxide based thermochemical water splitting cycle. J. Renew. Sustain. Energy 2016, 8, 034702. [CrossRef]

11. Takalkar, G.D.; Bhosale, R.R.; Kumar, A.; AlMomani, F.; Khraisheh, M.; Shakoor, R.A.; Gupta, R.B. Transition metal doped ceria for solar thermochemical fuel production. Sol. Energy 2018, 172, 204-211. [CrossRef]

12. Ashok, A.; Kumar, A.; Bhosale, R.; Saad, M.A.S.; AlMomani, F.; Tarlochan, F. Study of ethanol dehydrogenation reaction mechanism for hydrogen production on combustion synthesized cobalt catalyst. Int. J. Hydrog. Energy 2017, 42, 23464-23473. [CrossRef]

13. Budhavaram, N.K.; Fan, Z. Production of lactic acid from paper sludge using acid-tolerant, thermophilic Bacillus coagulan strains. Bioresour. Technol. 2009, 100, 5966-5972. [CrossRef]

14. Alkasrawi, M.; Rajangam, A.S.; Tawalbeh, M.; Kafiah, F.; Al-Othman, A.; Al-Asheh, S.; Sun, Q. Techno-economic analysis and a novel assessment technique of paper mill sludge conversion to bioethanol toward sustainable energy production. Int. J. Energy Res. 2020. [CrossRef]

15. Gurram, R.N.; Al-Shannag, M.; Lecher, N.J.; Duncan, S.M.; Singsaas, E.L.; Alkasrawi, M. Bioconversion of paper mill sludge to bioethanol in the presence of accelerants or hydrogen peroxide pretreatment. Bioresour. Technol. 2015, 192, 529-539. [CrossRef] [PubMed] 
16. Tawalbeh, M.; Rajangam, A.S.; Salameh, T.; Al-Othman, A.; Alkasrawi, M. Characterization of paper mill sludge as a renewable feedstock for sustainable hydrogen and biofuels production. Int. J. Hydrog. Energy 2020. [CrossRef]

17. Chen, H.; Venditti, R.A.; Jameel, H.; Park, S. Enzymatic hydrolysis of recovered office printing paper with low enzyme dosages to produce fermentable sugars. Appl. Biochem. Biotechnol. 2012, 166, 1121-1136. [CrossRef] [PubMed]

18. Guan, W.; Shi, S.; Tu, M.; Lee, Y.Y. Acetone-butanol-ethanol production from Kraft paper mill sludge by simultaneous saccharification and fermentation. Bioresour. Technol. 2016, 200, 713-721. [CrossRef] [PubMed]

19. Salameh, T.; Tawalbeh, M.; Al-Shannag, M.; Saidan, M.; Melhem, K.B.; Alkasrawi, M. Energy saving in the process of bioethanol production from renewable paper mill sludge. Energy 2020, 196, 117085. [CrossRef]

20. Huiliñir, C.; Quintriqueo, A.; Antileo, C.; Montalvo, S. Methane production from secondary paper and pulp sludge: Effect of natural zeolite and modeling. Chem. Eng. J. 2014, 257, 131-137. [CrossRef]

21. Chiang, K.-Y.; Lu, C.-H.; Liao, C.-K.; Ger, R.H.-R. Characteristics of hydrogen energy yield by co-gasified of sewage sludge and paper-mill sludge in a commercial scale plant. Int. J. Hydrog. Energy 2016, 41, 21641-21648. [CrossRef]

22. Lai, T.T.; Pham, T.T.H.; Adjallé, K.; Montplaisir, D.; Brouillette, F.; Barnabé, S. Production of Trichoderma reesei RUT C-30 lignocellulolytic enzymes using paper sludge as fermentation substrate: An approach for on-site manufacturing of enzymes for biorefineries. Waste Biomass Valorization 2017, 8, 1081-1088. [CrossRef]

23. Chen, H.; Venditti, R.; Gonzalez, R.; Phillips, R.; Jameel, H.; Park, S. Economic evaluation of the conversion of industrial paper sludge to ethanol. Energy Econ. 2014, 44, 281-290. [CrossRef]

24. Ye, L.; Lv, X.; Yu, H. Engineering microbes for isoprene production. Metab. Eng. 2016, 38, 125-138. [CrossRef] [PubMed]

25. Morais, A.R.C.; Dworakowska, S.; Reis, A.; Gouveia, L.; Matos, C.T.; Bogdał, D.; Bogel-Łukasik, R. Chemical and biological-based isoprene production: Green metrics. Catal. Today 2015, 239, 38-43. [CrossRef]

26. Lee, H.W.; Park, J.H.; Kim, W.K.; Lee, J.G.; Lee, J.S.; Ahn, J.O.; Lee, E.G.; Lee, H.W. Engineered Escherichia coli strains as platforms for biological production of isoprene. FEBS Open Bio 2020, 10, 780-788. [CrossRef]

27. Sluiter, A.; Hames, B.; Ruiz, R.; Scarlata, C.; Sluiter, J.; Templeton, D.; Crocker, D. Determination of structural carbohydrates and lignin in biomass. Lab. Anal. Proced. 2008, 1617, 1-6.

28. Resch, M.G.; Baker, J.O.; Decker, S.R. Low Solids Enzymatic Saccharification of Lignocellulosic Biomass: Laboratory Analytical Procedure (LAP); National Renewable Energy Laboratory: Golden, CO, USA, 2015.

29. Liu, H.; Sun, Y.; Ramos, K.R.M.; Nisola, G.M.; Valdehuesa, K.N.G.; Lee, W.K.; Park, S.J.; Chung, W.-J. Combination of Entner-Doudoroff pathway with MEP increases isoprene production in engineered Escherichia coli. PLoS ONE 2013, 8, e83290. [CrossRef] [PubMed]

30. Gräwert, T.; Kaiser, J.; Zepeck, F.; Laupitz, R.; Hecht, S.; Amslinger, S.; Schramek, N.; Schleicher, E.; Weber, S.; Haslbeck, M. IspH protein of Escherichia coli: Studies on iron-sulfur cluster implementation and catalysis. J. Am. Chem. Soc. 2004, 126, 12847-12855. [CrossRef] [PubMed]

31. Bentley, F.K.; Zubriggen, A.; Melis, A. Heterologous Expression of the mevalonic acid pathway in cyanobacteria enhances endogenous carbon partitioning to isoprene. Mol. Plant 2014, 7, 71-86. [CrossRef] [PubMed]

32. Gao, X.; Gao, F.; Liu, D.; Zhang, H.; Nie, X.; Yang, C. Engineering the methylerythritol phosphate pathway in cyanobacteria for photosynthetic isoprene production from $\mathrm{CO}_{2}$. Energy Environ. Sci. 2016, 9, 1400-1411. [CrossRef]

33. Yang, J.; Zhao, G.; Sun, Y.; Zheng, Y.; Jiang, X.; Liu, W.; Xian, M. Bio-isoprene production using exogenous MVA pathway and isoprene synthase in Escherichia coli. Bioresour. Technol. 2012, 104, 642-647. [CrossRef] [PubMed]

34. Liu, H.; Cheng, T.; Zou, H.; Zhang, H.; Xu, X.; Sun, C.; Aboulnaga, E.; Cheng, Z.; Zhao, G.; Xian, M. High titer mevalonate fermentation and its feeding as a building block for isoprenoids (isoprene and sabinene) production in engineered Escherichia coli. Process Biochem. 2017, 62, 1-9. [CrossRef]

35. Kim, J.-H.; Wang, C.; Jang, H.-J.; Cha, M.-S.; Park, J.-E.; Jo, S.-Y.; Choi, E.-S.; Kim, S.-W. Isoprene production by Escherichia coli through the exogenous mevalonate pathway with reduced formation of fermentation byproducts. Microb. Cell Factories 2016, 15, 214. [CrossRef] [PubMed] 
36. Al-Qodah, Z.; Al-Shannag, M.; Amro, A.; Bob, M.; Bani-Melhem, K.; Alkasrawi, M. Impact of surface modification of green algal biomass by phosphorylation on the removal of copper (II) ions from water. Turk. J. Chem. 2017, 41, 190-208. [CrossRef]

37. Al-Shannag, M.; Al-Qodah, Z.; Nawasreh, M.; Al-Hamamreh, Z.; Bani-Melhem, K.; Alkasrawi, M. On the performance of Ballota Undulata biomass for the removal of cadmium (II) ions from water. Desalin. Water Treat. 2017, 67, 223-230. [CrossRef]

C 2020 by the authors. Licensee MDPI, Basel, Switzerland. This article is an open access article distributed under the terms and conditions of the Creative Commons Attribution (CC BY) license (http://creativecommons.org/licenses/by/4.0/). 